\title{
Enhancement of growth and suppressing the root diseases of tomato plant by using organic amendment
}

\author{
Gulnaz Parveen ${ }^{1 *}$, Naila Mukhtar ${ }^{2}$, Kaleemullah $^{3}$ and Muhammad \\ Kamal Sheikh ${ }^{4}$ \\ 1. Department of Botany, Women University Swabi, Swabi-Pakistan \\ 2. Department of Botany, Government College University Faisalabad, Layyah Campus-Pakistan \\ 3. Department of Statistics, Women University Swabi, Swabi-Pakistan \\ 4. Planning and Development Division, Pakistan Agricultural Research Council-Pakistan \\ *Corresponding author's email: gulnaz.malik3@gmail.com \\ Citation \\ Gulnaz Parveen, Naila Mukhtar, Kaleemullah and Muhammad Kamal Sheikh. Enhancement of growth and \\ suppressing the root diseases of tomato plant by using organic amendment Pure and Applied Biology. Vol. 8, \\ Issue 2, pp1092-1099. http://dx.doi.org/10.19045/bspab.2019.80051

\begin{tabular}{llll}
\hline \hline Received: 25/01/2019 & Revised: 25/03/2019 & Accepted: 28/03/2019 & Online First: 04/04/2019 \\
\hline \hline
\end{tabular}

\section{Abstract}

Cotton (Gossypium hirsutum L.) and mustard (Brassica compestris L.) cake used to suppress pathogenic fungi and ultimately enhanced the growth of tomato (Lycopersicon esculentum) plant. During field experiment tomato plant was treated alone and combine use of mustard and cotton cake with different concentration viz, 1, 3 and 5\% W/V. Fusarium solani, Botrytis cinerea and Fusarium samitactum was completely controlled by the combine effect of mustered and cotton cake at $1 \% \mathrm{MC}+5 \% \mathrm{CC}$, similarly Rhizoctonia solani was completely controlled at $1 \% \mathrm{MC}+1 \% \mathrm{CC}$, while $5 \% \mathrm{MC}, 5 \% \mathrm{CC}, 1 \% \mathrm{CC}+5 \% \mathrm{MC}$ also showed the significant $(\mathrm{P}<0.05)$ result by reducing the percent infection of $F$. solani, $R$. solani at 11.11 each. Plant height enhanced significantly $(\mathrm{P}<0.05)$ by all treatments alone and combine, while maximum plant height and weight was produced by combine effect of mustard and cotton cake at $1 \% \mathrm{MC}+5 \% \mathrm{CC}$ was $14 \mathrm{~cm}$ and $23.41 \mathrm{~g}$ respectively.

Keywords: Cotton; Fungi; Lycopersicon esculentum; Mustard; Organic manure

\section{Introduction}

Organic soil amendments are not only safe to use and effective in controlling several plant pathogens present inside the soil like, root-knot nematode but also encourage soil biological activity and improve soil structure [1], Generally most common organic amendments are animal manure, peat moss, compost, wood chips, sewage sludge, sawdust and straw used in soil [2]. Organic amendments suppressed the soil borne pathogens, enhance the yield of crops $[3,4]$. Application of organic amendments improves structure, texture, color, humus, water holding capacity (WHC), aeration and microbial activity of soil, all these yield reduce environmental pollution and increase production [5-9]. Improved structure of soil [10] and micro-organism [11]. Organic fertilizer can work as alternative use of inorganic fertilizers [12]. Organic fertilizer stimulates different species of plant, which discharge plant hormones alternate to stimulate absorption of nutrients and the plant growth [13].

Research in developing countries like South East Asia and Nigeria showed that soil modification with different organic matters resulted in effective root knot 
nematode control and enhanced crop yield [14-16].

Numerous sources of organic matter available locally or regionally for controlling root infecting pathogen, a numeral of organic extracts of plant origin, like oil-cakes from plant extracts, used to develop soil structure [17]. Manure that obtained from plant biomass also used [1820].Two different types of oil cakes were found, non-edible and edible oilcakes, Edible oil cakes have nutritional significance; including $15 \%$ to $50 \%$ protein content [21]. Composition of oil cakes are varies depending on their extraction methods, growing form and on their variety. Due to the P N K contents of nonedible oil cakes, these cakes are used as organic fertilizers, enhanced to uptake the nitrogen and they also defend the plants from pathogens, nematodes, and insects; in this way it shows resistance against pathogens [21]. It is a very decent source of amino acids like lysine, methionine, tryptophan and threonine [22]. Amylase $[23,24]$, protease $[25,26]$ phytase, lipase [27] and glutaminase [28] and specific enzymes are produced by using these oil cakes as nutrient source. Oil cakes increase $\mathrm{N}$ uptake by the plants and check nitrification of the soil/urea, oil cakes comprising $2-7 \%$ of protein improve plant health and suppress soil nematodes [29]. In order to protect the crop nematodes, extracts of oil-cakes can also be used as seeds coating [30-32]. Oilseed press cakes prepared from cotton, mustard or other plant species suggested [33-36].

Mustard (Brassica compestris L.) symbolized by rape seed belongs to the genus Brassica of the family Brassicaceae (Cruciferae), it plays a very important role in human diet and is considered as the important oilseed crops in the world, mostly in Bangladesh [37]. In several mustard producing countries of the world it is used as a manure, condiment, salad and fodder crop and as a stem and leaf vegetable [37]. In Bangladesh local production of edible oil almost completely comes from rapeseed and mustard occupying only about $2 \%$ area of total cropped area [38]. The share of rapeseed-mustard was 0.21 million tons from the annual oil seed production of 0.41 million tons, which comes about $52 \%$ of the total edible oil seed production [39]. Brassica residues have been described to decrease the number of chlamydospore of FOL in tomato [40]. Mustard oil cake reduces galls of nematodes and ultimately improve the yield of tomato plant $[41,42]$. Oil seed cakes are rich in minerals, vitamins, proteins, antioxidants, fibers so they are used for feed preparation [43].

\section{Materials and methods \\ Plant material}

Tomato (Lycopersicon esculentum) Advanta 1204 ICI Pakistan lts seeds, Mustard and cotton cake were purchased from Swabi Market.

\section{Preparation of oil seed cake}

Oil seed cakes were obtained from Cotton (Gossypium herbaceum L.) and Mustard (Brassica campetris L.) and used to control root diseases and growth enhancement of tomato plants. Both these oil cakes (Cotton and Mustard) were dried, grinded in electric grinder and finally prepared $1 \% \mathrm{~W} / \mathrm{V}$, $3 \% \mathrm{~W} / \mathrm{V}$ and $5 \% \mathrm{~W} / \mathrm{V}$ solutions.

\section{Soil used for seedling}

Sandy loam soil with $\mathrm{pH} 8.0$ taken from a trial field of the Botanical Garden, Department of Botany, Women University Swabi, Swabi, Pakistan was sterilized and used for tomato seedling.

\section{Field Experiment}

Field Experiment was performed in the Botanical Garden, Women University Swabi in completely randomized block design. The soil was having natural invasion of $0-5 \%$ colonization of R.solani, 1-8 sclerotia/g of soil of Macrophomina phaseolina and $4600 \mathrm{cfu} / \mathrm{g}$ soil of $F$. solani. Solution of cotton cake and mustard cake of $1 \% \mathrm{~W} / \mathrm{V}, 3 \% \mathrm{~W} / \mathrm{V}$ and $5 \% \mathrm{~W} / \mathrm{V}$ were transferred from each concentration in sandy loam soil @ $1000 \mathrm{ml} / 2$ meters row, watered 2-3 days interval and let the organic matters to decompose. After two weeks of cotton cake and mustard cake 
decomposition, Three week old equal sized tomato seedlings were transplanted in oilseed cakes treated experimental field. Each treatment was replicated 3 times with 12 seedlings of each replicate. Seedlings were planted at the edges of the experimental field and watered twice a week subject to the condition of soil moisture and weather. Seedling transferred into the untreated rows of experimental field served as control. Observations were noted after 45 days of transplantation. Three plants from each replicate were uprooted to check the Infection caused by pathogens and subjected for further process.

\section{Root rotting fungi}

To find out the frequency of fungal infection in root, nine plants rooted out from each treatment and were washed under tap water and sterilized with $1 \%$ bleach. Then the root is cut into five equal pieces of $1 \mathrm{~cm}$ length and transferred on potato dextrose agar plats treated with penicillin $(100,000$ units / $\mathrm{L}$ and streptomycin $(0.2 \mathrm{~g} / \mathrm{L})$. Incubated for five days at $28{ }^{\circ} \mathrm{C}$, fungi appeared on root pieces after incubating period, were identified, infection and colonization percentage was calculated by following formula.

Infection $\%=$ No of plants infected by pathogen / Total No. of plants $\times 100$

Colonization $\%=$ No of root pieces colonized by pathogen / Total No. of root pieces of all Plants $\times 100$

Different growth parameters were also recorded.

\section{Statistical analysis}

The experiment was performed two times and data were recorded to analysis of variance (ANOVA). For growth parameter and fungal infection percentage were subjected to one-way ANOVA followed by the least significant difference LSD test at $\mathrm{P}=0.05$. All analysis was performed using IBM-SPSS STATISTICS program [44].

\section{Results and discussion}

\section{Field experiment}

$F$. solani infection was completely controlled by the combine effect of mustard and cotton cake at $1 \% \mathrm{MC}+5 \% \mathrm{CC}$, While significant maximum reduction in infection of $F$. solani found at $5 \% \mathrm{MC}, 5 \% \mathrm{CC}$, $1 \% \mathrm{CC}+5 \% \mathrm{MC}$ and $1 \% \mathrm{CC}+3 \% \mathrm{MC}$. Application of mustard and cotton cake at $1 \% \mathrm{MC}+1 \% \mathrm{CC}$ showed complete suppression of R.solani. Significant reduction of $M$. phaseolina was recorded by the use of $3 \% \mathrm{CC}, 5 \% \mathrm{MC}, 5 \% \mathrm{CC}$, $1 \% \mathrm{MC}+1 \% \mathrm{CC}, \quad 1 \% \mathrm{MC}+3 \% \mathrm{CC}$, $1 \% \mathrm{MC}+5 \% \mathrm{CC}, 1 \% \mathrm{CC}+5 \% \mathrm{MC}$. Complete suppression of $F$. samitactum and B.cinerea was found by $1 \% \mathrm{MC}+5 \% \mathrm{CC}$ while $B$. cinerea was also completely controlled by combine effect of mustard and cotton cake at $1 \% \mathrm{MC}+3 \% \mathrm{CC}$. The combination of $1 \%$ $\mathrm{CC}+5 \% \mathrm{MC}$ show equal and minimum reduction $(11.11 \%)$ for all root rotting fungi (Table 1).

Greater plant height and weight was produced at $1 \% \mathrm{MC}+5 \% \mathrm{CC}$, while all treatments $(1 \% \mathrm{MC}, 1 \% \mathrm{CC}, 3 \% \mathrm{MC}$, $3 \% \mathrm{CC}, 5 \% \mathrm{MC}, 5 \% \mathrm{CC}, 1 \% \mathrm{MC}+1 \% \mathrm{CC}$, $1 \% \mathrm{MC}+3 \% \mathrm{CC}, 1 \% \mathrm{MC}+5 \% \mathrm{CC}, 1 \% \mathrm{CC}$ $+3 \% \mathrm{MC}$, and $1 \% \mathrm{CC}+5 \% \mathrm{MC}$ ) enhanced plant height significantly (Figure 1) (Table 2).

Use of inorganic chemical to control root rotting fungi and plant parasitic nematodes is very effective but also caused soil pollution [45]. Application of bio-control agent is very effective and alternative method in the replacement of pesticides to control the root rotting fungi $[46,47]$.

In the current study, use of organic amendment such as cotton cake and mustard cake reduce $F$. solani, $R$. solani, $B$. cinerea and $M$. phaseolina infection on tomato plant. Organic amendment could kill pathogenic fungi and resulting in increased in yield. [48] Studied that organic amendments produced significant effect against disease of tomato produced by Fusarium specie. Use of mustard cake enhanced nutrients availability and plant uptake growth [49]. Present result indicates increase in growth parameters when cotton cake and mustard cake is coated to seeds, colonization percentage of $M$. phaseolina was observed less [50]. It suggested that 
combine used of cotton and mustard cake to seed were found to be very effective in controlling infection of $M$. phaseolina on roots of plants. [51] Conducting field trial during Rabi season from 2001-2004 for management of wilt disease, induced by Fusarium through soil amendment with two oil cakes viz, cotton and mustard cake. The increase in length of plant due to organic manure also increases the fertility of soil [52, 53] observed that soil had significant effect when used with oil cakes on seed germination and plant size. In the present study different growth factors of tomato plant were observed, the plant showed significant $(\mathrm{p}<0.05)$ greater root and shoot length $12.47 \mathrm{~cm}$ and $14 \mathrm{~cm}$ respectively at the rate of $1 \% \mathrm{MC}+5 \% \mathrm{CCw} / \mathrm{w}$. Thus, amendment of soil with Cotton and Mustard cake was effective and enhanced the growth of tomato plant and also suppressed the pathogens compared to control.

Table 1. Effect of organic amendment on the infection\% of root rotting fungi

\begin{tabular}{|c|c|c|c|c|c|}
\hline \multicolumn{7}{|c|}{ Infection \% } \\
\hline Treatments & $\boldsymbol{F}$. solani & M. phaseolina & $\boldsymbol{R}$. solani & B. cinerea & F. samitactum \\
\hline Control & 100.00 & 77.77 & 33.33 & 66.66 & 33.33 \\
\hline $1 \%$ MC & 55.55 & 44.44 & 22.22 & 33.33 & 55.55 \\
\hline $1 \%$ CC & 77.7 & 44.44 & 11.11 & 44.44 & 22.22 \\
\hline $3 \%$ MC & 55.55 & 66.66 & 44.44 & 44.44 & 22.22 \\
\hline $3 \%$ CC & 66.66 & 33.33 & 11.11 & 22.22 & 22.22 \\
\hline $5 \%$ MC & 11.11 & 11.11 & 22.22 & 11.11 & 11.11 \\
\hline $5 \%$ CC & 11.11 & 11.11 & 11.11 & 0.00 & 11.11 \\
\hline $1 \%$ MC $+1 \%$ CC & 66.66 & 33.33 & 0.00 & 33.33 & 33.33 \\
\hline $1 \%$ MC $+3 \%$ CC & 55.55 & 22.22 & 11.11 & 0.00 & 11.11 \\
\hline $1 \%$ MC $+5 \%$ CC & 0.00 & 11.11 & 11.11 & 0.00 & 0.00 \\
\hline $1 \%$ CC +3\% MC & 22.22 & 44.44 & 33.33 & 11.11 & 22.22 \\
\hline $1 \%$ CC $+5 \%$ MC & 11.11 & 11.11 & 11.11 & 11.11 & 11.11 \\
\hline \multicolumn{7}{|c|}{ LSD $(0.05)$} & 26.48 & 32.43 & 28.08 & 28.08 & 28.08 \\
\hline
\end{tabular}

Table 2. Effect of organic amendments on the growth of Tomato plant

\begin{tabular}{|l|l|l|l|l|}
\hline Treatment & Root length & Shoot length & Root weight & Shoot weight \\
\hline Control & 2.42 & 5.03 & 0.49 & 1.16 \\
\hline $1 \% \mathrm{MC}$ & 3.57 & 6.20 & 0.66 & 1.60 \\
\hline $1 \% \mathrm{CC}$ & 4.49 & 9.83 & 1.45 & 5.05 \\
\hline $3 \% \mathrm{MC}$ & 4.05 & 8.00 & 1.38 & 3.44 \\
\hline $3 \% \mathrm{CC}$ & 9.51 & 12.00 & 2.58 & 10.90 \\
\hline $5 \% \mathrm{MC}$ & 6.03 & 10.33 & 2.02 & 5.46 \\
\hline $5 \% \mathrm{CC}$ & 9.88 & 13.67 & 13.20 & 22.75 \\
\hline $1 \% \mathrm{MC}+1 \% \mathrm{CC}$ & 6.89 & 8.53 & 1.33 & 3.11 \\
\hline $1 \% \mathrm{MC}+3 \% \mathrm{CC}$ & 10.06 & 12.33 & 3.017 & 11.48 \\
\hline $1 \% \mathrm{MC}+5 \% \mathrm{CC}$ & 12.47 & 14.00 & 14.08 & 23.41 \\
\hline $1 \% \mathrm{CC}+3 \% \mathrm{MC}$ & 4.48 & 9.33 & 2.74 & 4.54 \\
\hline $1 \% \mathrm{CC}+5 \% \mathrm{MC}$ & 5.89 & 13.33 & 2.71 & 6.90 \\
\hline $\mathrm{LSD}(0.05)$ & $0.70^{(1)}$ & $1.20^{(1)}$ & $0.58^{(1)}$ & $1.02^{(1)}$ \\
\hline
\end{tabular}

${ }^{(1)}$ Mean values of treatments in columns show a difference in LSD values that are significantly different at $(\mathrm{p}<0.05)$ 

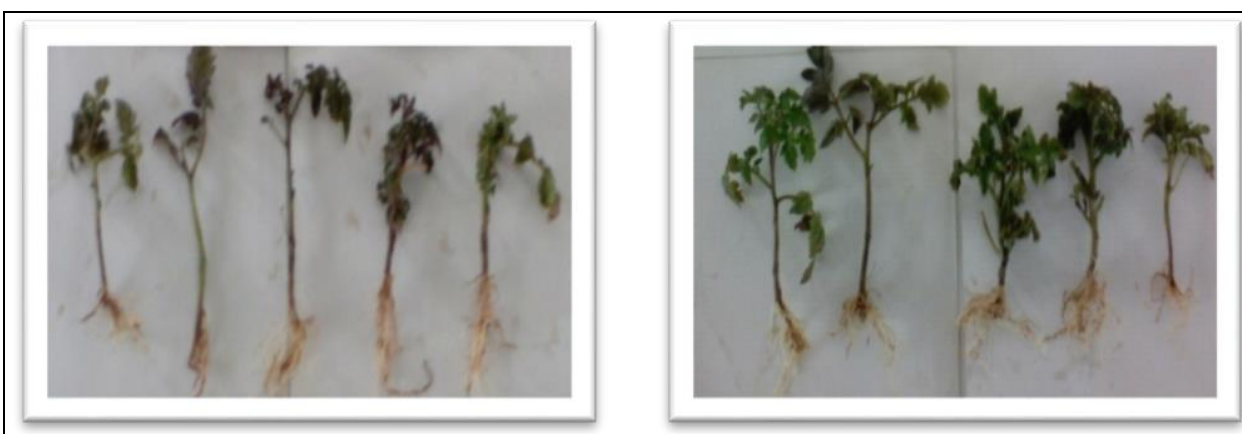

A

B
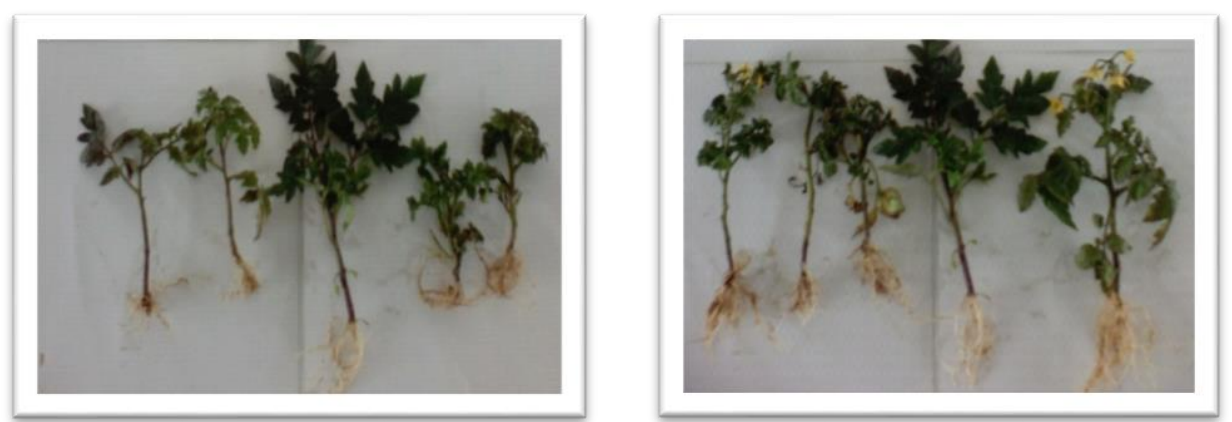

$\mathrm{C}$

$\mathrm{D}$
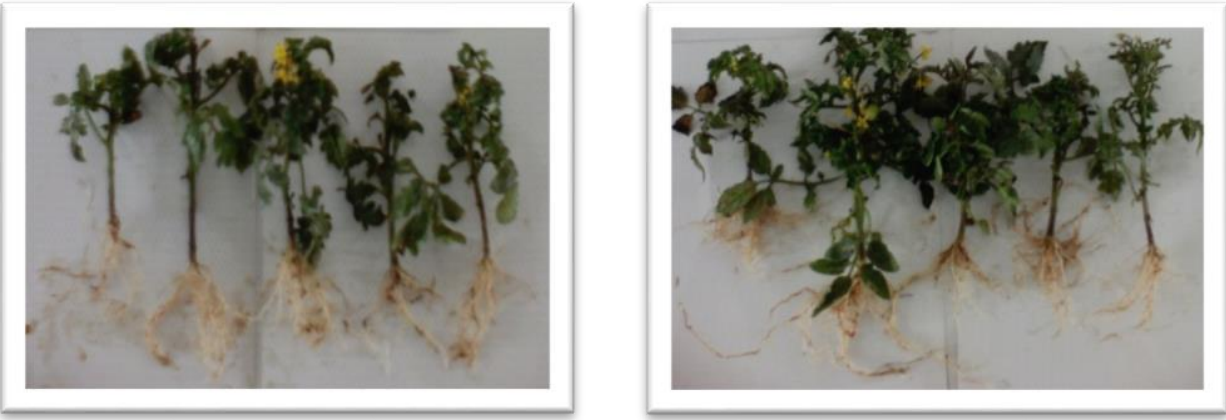

E

F

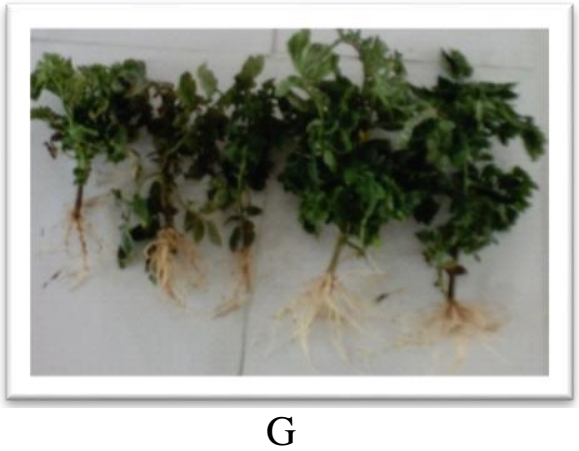

Figure 1. Combine effect of cotton and mustard cake on the growth of tomato plant. $\mathrm{A}=$ Control, $\mathrm{B}=3 \% \mathrm{MC}, \mathrm{C}=1 \% \mathrm{MC}, \mathrm{D}=5 \% \mathrm{MC}, \mathrm{E}=1 \% \mathrm{CC}, \mathrm{F}=1 \% \mathrm{MC}+3 \% \mathrm{CC}, \mathrm{G}=$ $1 \% \mathrm{MC}+5 \% \mathrm{CC}$ 


\section{Conclusion}

Mustard and Cotton oil cakes alone or mixed could be used as manure for management of soil-borne diseases and growth enhancement of tomato plant.

\section{Authors' contributions}

Conceived and designed the experiments: G Parveen, Performed the experiments: $G$ Parveen, Analyzed the data: Kaleemullah Contributed materials/ analysis/ tools: G Parveen \& MK Sheikh, Wrote the paper: G Parveen \& N Mukhtar.

\section{References}

1. Koivunen EE, Tully $\mathrm{K}$ \& Swett $\mathrm{C}$ (2018). Co-managing soil and plant pathogens: effects of organic amendments on soil fertility and fungal pathogen survival. Plant Soil 432(3): 171-189.

2. Goss MJ, Tubeileh A \& Goorahoo D (2013). A review of the use of organic amendments and the risk to human health. Adv Agron 120: 275-379.

3. Stone AG, Vallad GE, Cooperband LR, Rotenburg DR, Darby HM, Stevenson WR \& Goodman RM (2003). Impact of annual organic amendment on disease incidence in a three year vegetable rotation. Plant Dis, 87: 1037-1042.

4. Ali NI, Siddiqi IA, Zaki MJ \& Shaukat SS (2001). Nematicidal potential of Lantana camara against Meloidogyne javanicain mungbean. Nematologia Mediterranea, 29: 99-102.

5. Pare T, Danial H \& Schnitzer M (2000). Carbon and nitrogen minrelization in soil amended with non-stabilize and stabilize poultry manure. Canadian $J$ Soil Sci 80(2): 271-282.

6. Saha R, Mishra VK, Majumdar B, Laxminarayana K \& Ghosh PK (2010). Effect of integrated nutrient management on soil physical properties and crop productivity under a maize (Zea mays L.) - mustard (Brassica campestris L.) cropping sequence in acidic soils of northeast India. Commun Soil Sci Plant Analy 41(18): 2187-2200.

7. Ingle SN, Malode SV, Ghodpage RM \& Jadhav SD (2004). Effect of long term use of vegetative barriers and FYM on yield and soil fertility under cottonsorghum rotation in vertisol. Annal Plant Physiol 18(1): 42-44.

8. Davies G \& Lennartson M (2005). Organic vegetable production: a complete guide. Crowood Publishers, Marlborough (UK). Pp 350

9. Oka Y (2010). Mechanisms of nematode suppression by organic soil amendments-a review. Appl Soil Ecol 44: 101-115.

10. Dauda SN, Ajayi FA \& Ndor E (2008). Growth and yield of water melon (Citrullus lanatus) as affected by poultry manure application. J Agric Soc Sci 4: 121-124.

11. Suresh KD, Sneh G, Krishn KK \& Mool CM (2004). Microbial biomass carbon and microbial activities of soils receiving chemical fertilizers and organic amendments. Arch Agron Soil Sci 50: 641-647.

12. Naeem M, Iqbal J \& Bakhsh MAA, (2006). Comparative Study of Inorganic Fertilizers and Organic Manures on Yield and Yield Components of Mungbean (Vigna radiate L.). J Agric Soc Sci 2: 227-229.

13. Arisha HME, Gad AA \& Younes SE (2003). Response of some pepper cultivars to organic and mineral nitrogen fertilizer under sandy soil conditions. Zagazig J Agric Res 30:1875-99.

14. Ewulo BS, Ojeniyi SO \& Akanni DA (2008). Effect of poultry manure on selected soil physical and chemical properties, growth, yield and nutrient status of tomato. African J Agric Res 3(9): 612-616.

15. Adekiya AO \& Agbede TM (2009). Growth and yield of tomato (Lycopersicon esculentum Mill) as influenced by poultry manure and NPK fertilizer. Emirates J Food Agric 21(1): 10-20.

16. Ogwulumba Si, Ugwuoke KI \& Ogbuji RO (2010). Studies on Meloidogyne javanica infestation on Roma tomato (Lycopersicon esculentum Mill) under different soil amendments. African $J$ Biotechnol 9: 3280-3283. 
17. Akhtar M \& Alam MM (1993). Utilization of waste materials in nematode control: A review. Bioresour Technol 45: 1-7.

18. Vedoveto $\mathrm{M} \mathrm{V} \mathrm{V}$, Dias-Ariera CR, Rodrigues DB, Ariera JO, Roldi M \& Severino JJ. (2013). Green manure in the management of Pratylenchus brachyurusin soybean. Nematropica 43 : 226-232.

19. Rodriguez-Kabana R (2014). Organic and inorganic nitrogen amendments to soil as nematode suppressants. $J$ Nematol 18: 129-135.

20. Costa, M J N, Pasqualli RM, \& Prevedello R (2014). Effect of soil organic matter content, cover crop and planting system on the control of Pratylenchus brachyurusin soybean. Summa Phytopathologica 40: 63-70.

21. Ramachandran S, Patel KP, Nampoothiri KM, Francis F, Nancy V, Szakacs G \& Pandey A (2004b). Coconut oil cake a potential raw material for the production of $\alpha$-amylase. Biores Technol 93(2):169-172.

22. Swick RA (1999). Considerations in using protein meals for poultry and swine. ASA Tech Bull 21: 1-11.

23. Ramachandran S, Patel KP, Nampoothiri KM, Sandhya C, Szakacs G, Soccol CR $\&$ Pandey A (2004a). $\alpha$-amylase from a fungal culture grown on oil cakes and its ties. Brazilian Arch Biol Technol 47(2):309-318.

24. Ramachandran S, Singh SK, Larroche C, Soccol CR \& Pandey A (2007). Oil cakes and their biotechnological applications - A review. Biores Techno 98: 2000-2009.

25. El-Sherif AG, Refaei AR, El-Nagar ME \& El-GhnamHeba AA (2006). Impact of certain organic amendments, Bacillus thuringiensis and Oxamyl on Tylenchulus semipenetrans infecting Lemon plant. J Agric Sci Mansoura Univ 3: 6761-6770.

26. Sumantha A, Sandhya C, Szakacs G, Soccol CR \& Pandey A (2005). Production and partial purification of a neutral metalloprotease by fungal mixed substrate fermentation. Food Technol Biotechnol 43: 313-319.

27. Sabu A, Sarita S, Pandey A, Bogar B, Szakacs G \& Soccol CR (2002). Solidstate fermentation for production of phytase by Rhizopus oligosporus. Appl Biochem Biotech pp: 251-260.

28. Kashyap P, Sabu A, Pandey A, Szakacs G \& Soccol CR (2002). Extracellular Lglutaminase production by Zygosaccharomyces rouxiiunder solidstate fermentation. Process Biochem 38 307-312.

29. Tiyagi SA, Khan AV\& Alam MM (2002) Biodegradable effect of oil seed cakes on plant-parasitic nematodes and soil inhabiting fungi infesting Trigonella foenum greacum and Phaseolus aureus. Indian J Nemat 32: 47-57.

30. El-Sherif AG, Refaei AR, El-Nagar ME and El-GhnamHeba AA (2006). Impact of certain organic amendments, Bacillus thuringiensis and Oxamyl on Tylenchulus semipenetrans infecting Lemon plant. J Agric Sci Mansoura Univ 3: 6761-6770.

31. El-Sherif AG, Refaei AR, El-Nagar ME \& Salem MMH (2010). Impact of certain oil-seed cakes or powder in comparison with oxamyl or urea on Meloidogyne incognita infecting eggplant. Arch Phytopathol Plant Protect 43: 88-94.

32. Youssef MMA \& El-Nagdi WMA (2010). Effect of certain organic materials in controlling Meloidogyne incognita root-knot nematode infesting banana. Arch Phytopathol Plant Protect 43: 660-665.

33. Umar I \& Simon SY (2008). The effect of oil seed cakes and ploughing against plant parasitic nematodes on cowpea (Vigna unguiculata (L.) Walp). Agric J 3:349-352.

34. Lopes E A, S. Ferraz OD, Dhingra PA, Ferreira \& Freitas LG. (2008). Soil amendment with castor bean oilcake and jack bean seed powder to control Meloidogyne javanica on tomato roots. Nemat Bras 33: 106-109.

35. Mohan K (2011). Comparison of inorganic and organic nematicides on the population of soil nematodes in hybrids 
of Saccharum species. J Biopest 4(2): 201-204.

36. Tiyagia S A, Mahmooda I, Khana Z \& Ahmad H (2011). Biological control of soil-pathogenic nematodes infecting mungbean using Pseudomonas fluorescence. Arch Phytopath Plant Protec 44: 1770-1778.

37. FAO (2004). Production Year Book. Food and Agricultural of the United Nations Rome, Italy. 82: 190-193.

38. BBS (2002). Monthly Statistical Bulletin of the Bangladesh Bureau of Statistics (August). Administration and MIS Wing, Bangladesh Secretariat, Dhaka. Pp: 122-139.

39. BBS (2009). Monthly Statistical Bulletin of the Bangladesh Bureau of Statistics (August). Administration and MIS Wing, Bangladesh Secretariat, Dhaka. Pp: 122-139.

40. Smolinska V (2000). Survival of Sclerotium cepivorum and Fusarium oxysporum Chlamydospores in soil amended with cruciferous residues. $J$ Phytopath 148:343-349.

41. Bharadwaj A \& Sharma S (2006). Biocontrol of Meloidogyne incognita in Lycopersicon esculentum with AM fungi and oil cakes. Plant Pathol J 5: 166-172.

42. Meena P, Nehra S \& Trivedi PC (2009). Efficacy of decomposed organic cakes against Heterodera cajan infecting Cajanus cajan. Asian J Exp Sci 23: 181184.

43. Sunil L, Appaiah P, Kumar PKP \& Krishna AGG (2015). Preparation of food supplements from oilseed cakes. $J$ Food Sci Technol 52(2): 2998-3005.

44. Sokal RR \& Rohlf FJ (1995). Biometry: the principles and practice of statistics in biological research. $2^{\text {nd }}$ Ed. Freeman Publishers.

45. Sukul S, Sinhababu P, Datta SC, Nandi B \& Sukul A (2001). Nematoxic effect of Acacia auriculiformis and Artemisia nilagirica against root-knot nematdoes. Allelopath J 8: 65-72.

46. Ehteshamul-Haque SM, Abid A \& Ghaffar A (1995). Efficacy of Bradyhrizobium and Paecilomyces with oil cake in the control of root rot of mungbean. Trop Sci 35(3): 294-299.

47. Ehteshamul-Haque S, Abid M, Sultana V, Ara J \& Ghaffar A (1996). Use of organic amendment on the efficacy of biocontrol agent in the control of root rot and knot disease complex of okra. Nematol Medit 24: 13-16.

48. Padmodaya B \& Reddy HR (1999). Effect of organic amendment on seedling disease of Tomato caused by Fusarium oxysporum f. sp. Lycoperscici. J Mycol Plant Pathol 29(1): 38-41.

49. Lewis KL, Frank MH \& Terry JG (2019). Beneficial use of white and Indian mustard seed Meals to enhance plant growth and nutrient uptake. Agrosyst Geosci Environ 2: 1-10.

50. Dawar S, Hayat S, Anis M \& Zki MJ (2008). Effect of seed coating material in the efficacy of microbial antagonists for the control of root rot fungi on okra and sunflower. Pak J Bot 43: 120-127.

51. Mathur K, Bansal RK \& Gurjar RBJ (2006). Organic management of Fusarium wilt of fenugreek (Trigonella foenumgraecum L.). A seed spice. $J$ Mycol Plant Pathol 29(1): 38-41.

52. Saidu A, Bello LY, Tsado EK \& Ibrahim FK (2011). Effect of cow dung on the performance of tomato. Inter J App Biol Res 6(5): 130-134.

53. Sultana N \& Gaffar A (2010). Effect of fungicides, microbial antagonists and oilcake in the control of Fusarium solani, the cause of seed rot, seedling and root infection of bottle gourd, bitter gourd and cucumber. Pak J Bot 42(4): 2921-2934. 